\title{
A SPORTOLÁS HATÁSA KISKAMASZOK ÉNKÉPÉRE, SZORONGÁSÁRA ÉS MEGKÜZDÉSÉRE
}

Szerzők:

Kovács Karolina Eszter
Debreceni Egyetem

Nagy Beáta Erika

Debreceni Egyetem

Első szerző e-mail címe:

karolina92.kovacs@gmail.com

\section{Lektorok:}

Kovács Klára

Debreceni Egyetem

Orosz Róbert

Debreceni Egyetem

Mező Ferenc

Debreceni Egyetem

Schéder Veronika

Debreceni Egyetem

Kovács Karolina Eszter és Nagy Beáta Erika (2015): A sportolás hatása kiskamaszok énképére, szorongására és megküzdésére. Különleges Bánásmód, I. évf. 2015/3. szám, 43-56.

DOI 10.18458/KB.2015.3.43

\begin{abstract}
Absztrakt
Jelen tanulmány a sportolás énképre, szorongásra, pszichológiai immunkompetenciára és teljesítményigényre gyakorolt hatásaira fókuszál prepubertások körében. Minta: 47 sportoló (kézilabdázó) és 46 nem sportoló fiú alkotta a mintát (kor: 11-13 év). Módszer: Coopersmithféle önértékelési kérdöiv (Coopersmith, 1984), a Spielberger féle Vonás- és Állapotszorongás Kérdöiv (STAI, Spielberger, 1973), a Teljesitményigény kérdöív (Tóth, 2005), illetve a Pszichológiai Immunkompetencia Junior Kérdöív (PIK-J, Oláh, 2005). Eredmény: a sportolás hatékony az önértékelés és megküzdés növelésében, illetve a szorongás és a túlzott megfelelési igény csökkentésében. Mivel ezek a tényezök egymástól nem függetlenek, így az egyikben bekövetkezö pozitív változás a többi faktorban is pozitív változást eredményez.
\end{abstract}

Kulcsszavak: sport, megküzdés, szorongás, prepubertás

Diszciplina: pszichológia

\footnotetext{
Abstract

EFFECT OF SPORT ON SELF-ESTEEM, ANXIETY AND COPING OF EARLY ADOLESCENTS

This paper is about the effect of sport participation on self-esteem, anxiety, psychological immune system and achievement motivation among early adolescents. Sample: 47 athletes (handballers) and 46 non-athletes boys took part in this research (age: 11-13 years). Methods: Coopersmith Self-esteem Inventory (Coopersmith, 1984), Spielberger State-Trait Anxiety Inventory for Children (STAI, Spielberg, 1973), Achievemnt Motivation Scale (Tóth, 2005) and Psychological Immune System Inventory Junior (PIK-J, Oláh, 2005). Results: sport
} 
increases self-esteem and coping, decreases anxiety and achievement motivation. Furthermore these factors are not independent so positive changes in one field cause positive changes in others as well.

Keywords: sport, coping, anxiety, early adolescence

Discipline: psychology

Napjainkban nagyon sok figyelmet kap az egészséges életmód: a megfelelő életvitel, a helyes és kiegyensúlyozott táplálkozás, a rendszeres testmozgás. Mindannyiunk érdeke, hogy az egészségtudatos életmódnak megfelelően éljünk, hiszen ez meghatározza egészségi állapotunkat, közérzetünket, sőt jövőnket is. A mozgás az egészséges életmód egyik alapköve, a megfelelő módon űzött sporttevékenység hatásai egyértelmüen pozitívak. Rendkívül fontos a mozgás jelentőségének hangsúlyozása a fiatalok számára, hiszen ha már gyerekkorban beépül az életvitelünkbe a mozgás, nagyobb valószínüséggel tart felnőttkorban is, vagy akár egész életen át (Ajzen, 2011).

A sporttevékenység mögött természetesen számos tényező állhat. A különböző életkorokban, társadalmi csoportokban, vagy akár nemenként is eltérő aktivitási formák jelennek meg. Fontos már gyerekkorban hangsúlyozni a mozgás szükségességét, hiszen minél hamarabb beépül a gyermek értékrendszerébe a sport, annál valószínűbb, hogy hosszú távon is szerves részét képezi mindennapjainak (Gyömbér és Kovács, 2012). A serdülőkor egy kritikus életszakasz, amikor számos nehézséggel kell megbirkóznia a fiatalnak, míg felnőtté válik. Önértékelésük még nem kifejlett és keresik helyüket a világban (Vajda, 2006). Mindazonáltal a sport jótékony hatásai náluk is megjelennek, sőt segíthetik őket életük számos terén: a beilleszkedésben, baráti kapcsolatok kialakításában, jobb megküzdésben és az

élet egyéb területein is. A tanulmány a sportoló és nem sportoló kiskamaszok önértékelését és megküzdését hivatott vizsgálni (Gyömbér és Kovács, 2012).

\section{A sportolás hatásai}

A rendszeres fizikai aktivitás számos jótékony hatása ismert. Fiziológiai szempontból az egészségre gyakorolt jótékony hatások mindenképp kiemelendők:

- javítja a szív-és keringési rendszer müködését (az erek rugalmasabbá válnak és a szívizmok is stabilabbak lesznek), továbbá a pulzusszám is lecsökken;

- a légzőrendszer oxigénfelvevő képessége nő;

- javul a mozgáskoordináció;

- jótékonyan hat az idegrendszerre és az immunrendszerre;

- valamint a megfelelő testsúlyelérésében és megtartásában is segít, csak a legfontosabbakat említve (Lénárt, 2002, Gyömbér és Kovács, 2012).

Pszichológiai szempontból kiemelendő az önismeret (például az igényszint, a motiváció, a kitartás és küzdőképesség) és önbizalom növekedése, a szorongás és feszültség érzés csökkenése, a figyelem és koncentrációs képesség javulása. Egyúttal segítség az érzelmi egyensúly elérésében is, javítja az alvás minőségét és az általános közérzetet is, valamint örömérzetet és sikerélményeket eredményez, a legfontosabb szempontokat kiemelve (Lénárt, 2002, Gyömbér és Kovács, 2012).

$\mathrm{Az}$ önértékelést tekintve elmondható, hogy a sportoló a sportolás során szerzett tapasztalatait részben képes hasznosítani életének más területén is. A sporttevékenység hozzájárul az egyén fejlődéséhez, egészségi állapotának megerősítéséhez, a fizikai képességeinek és mozgáskultúrájának fejlődéséhez, valamint a szabadidő kulturált és hasznos 
kitöltéséhez is (Stuller, 1995). Mahoney (2005) úgy gondolta, hogy gyerekeknél a sportolás szerepe jelentős személyiségük alakulását tekintve, mert azon aktivitások, amelyek alatt a gyermek kompetenciája épülöfélben van, különösen kritikusak fejlödésük formálódásában, hiszen a gyerekek ebben az életkorban megnövekedett fókusszal figyelik saját teljesítményüket, kompetenciájukat (Mahoney, 2005, idézi Slutzky és Simpkins, 2008).

Hazai és nemzetközi kutatások egyaránt megállapították, hogy a fizikailag aktív fiatalok egészségesebben táplálkoznak és kevesebbet dohányoznak, továbbá kevesebbet tévéznek, hasznosabban töltik el szabadidejüket, valamint a túlsúly kialakulásának kockázata is csökken náluk (Pate, Heath és tsai, 1996; Steptoe, Wardle és tsai, 1997; Kovács, 2015). Alapvetően megállapítható, hogy közérzetük is jobb, valamint jobb edzettségi és egészségi állapotról számolnak be, tehát a sportolói magatartás a jobb életminősséggel is párhuzamba állítható. Elégedettebbek az életükkel és kevesebb depresszív tünetről számolnak be. Az értékekhez való hozzáállás is eltérő lehet sportoló és nem sportoló gyerekek között: a rendszeresen sportoló serdülők inkább a belső értékorientációs módokat preferálják (pl. önelfogadás, csoporthoz tartozás, közösségi érzés, fizikai egészség), míg az alacsony aktivitású fiatalok a külső értékorientációs módokat értékelik nagyra (pl. anyagi siker, jó megjelenés, hírnév) (Pluhár, Keresztes és Pikó, 2004, idézi Pikó és Keresztes, 2007; Kovács, 2015).

Nagyon fontos, hogy a kiskamasz el tudja különíteni sportoló énjét saját énképén belül. Sajnos a sportoló fiatalok, különösen az élsportolók, hajlamosak saját énképüket teljes mértékben azonosítani sportolói énképükkel, ezért gyakran érezhetik azt, ha kudarcot vallanak a sportban, akkor az élet más területén is sikertelenek és értéktelen lesznek, illetve ha sikert érnek el a sportolóként, akkor emberként is sikeresek. (Gyömbér és Kovács, 2012). Számos kutatás támasztja alá azt a megállapítást, hogy a sportolók magasabb önértékeléssel rendelkeznek. Maguk a sportolók is úgy gondolják, hogy jobb az énképük és önértékelésük, mint nem sportoló társaiknak (Fletcher, Nickerson és Wright, 2003; Simpkins és tsai, 2006).

A sportoló énképét természetesen befolyásolja teljesítménye és feladatvállalása is, amely személyenként változó. Egy sportoló céljai akkor reálisak, ha enyhén meghaladják az egymás után megvalósított teljesítményt. Az aktuális teljesítmény és az ennél kicsit magasabb célkitüzés közti különbség optimális mértékü és motiváló hatású feszültséget eredményez, ami javíthatja a teljesítményt. Ha azonban nem optimális a különbség a várható teljesítmény és a cél között, problémák jelentkezhetnek: a túl magasra helyezett mérce okán szorongás és ezáltal teljesítménycsökkenés következik be, ám a túl alacsonyra helyezett mérce sem javít a teljesítményen. Ez utóbbi tipikusan kudarckerülő személyek esetében fordul elő, míg a sikerorientált személy igényszintje reális, optimális mértékü kockázatvállalással (Lénárt, 2002).

Az üzött sportág tekintetében eltérő hatások jelentkezhetnek: egyéni és csapatsportok között óriási különbségek vannak. A sporttevékenység változást eredményez a visszajelzési folyamatokban és a kortársak közti összehasonlításokban, ám a különböző sportágak másként befolyásolhatják a gyermek konzekvenciáit énképéröl (Horn és Hasbrook, 1987; Horn és Weiss, 1991; Roberts és Treasure, 1992). Továbbá a csapatsportok a serdülő számára sokkal inkább pozitív tapasztalatokat nyújtanak (például jobb kezdeményező készség vagy magasabb élettel való elégedettség) (Hansen, 2006; Vihjajmsson és Thorlindsson, 1992). Ugyanakkor az edzői visszajelzések kiemelkedő jelentőségüek, mert a rossz edzői kommunikáció jelentős károkat okozhat a gyermek önértékelésében. Ezen oknál fogva nagyon fontos, hogy az edző őszinte és kongruens legyen a kiskamasszal, amikor visszajelez felé (Lénárt, 2002).

Nagyon fontos kiemelni azonban a rendszeres sportolás kapcsán, hogy a hangsúly a megfelelő mennyiségen és módon van. A túlzásba vitt sport miatt káros hatások is jelentkezhetnek: sérülés, nem reális vagy negatív önbecslés, torzult testkép, káros szociális készségek kifejlesztése vagy pszichológiai sérülés, vagy sikertelenségtől való félelem (Smoll, 1998, idézi Gyömbér és Kovács, 2012). 


\section{Szorongás és megküzdés a sportban}

A szorongás és a félelem egy adott fenyegetésre felfogott normális válasz. A két jelenség közti különbség abban rejlik, hogy míg a félelem alapja többnyire egy jól körülhatárolt konkrét fenyegetés, addig a szorongást valamilyen homályos vagy rosszul felfogott fenyegetés váltja ki. Kellemetlen, feszült érzelmi állapotot takar, együtt jár a vegetatív idegrendszer magas aktivációjával, valamint negatív érzésekkel és gondolatokkal. Atkinson a szorongást a stresszre adott válaszok egyik fajtájának tekinti (Atkinson és mtsai, 2005).

Spielberger (1975) a szorongás két típusát különítette el: vonás-, illetve állapotszorongást. Az állapotszorongás csupán bizonyos szituációkban jelenik meg (például versenyen, vizsgán, stb.), míg az állapotszorongás esetében a szorongás az egyénnél hajlamszerúen jelentkezik, tehát mint a személyiség vonása. Ezzel szemben Liebert és Morris (1967) kognitív és szomatikus szorongást különített el. A kognitív szorongás a tartós aggodalmakban, töprengésekben és rágódásokban jelenik meg, velejárója a koncentrációra való képtelenség. Ezzel szemben a szomatikus szorongás a szorongásos tapasztalatok pszichológiai és érzelmi aspektusai, amelyek közvetlenül a vegetatív arousalból alakul ki. Gould és tsai (1987) úgy gondolták, hogy a szomatikus szorongás közvetlenül befolyásolja a teljesítményt (Marchant és Morris, 2005).

A szorongást vizsgálva elkülöníthetünk fizikai, affektív (érzelmi) és kognitív (értelmi) szintü összetevőket (Orosz, 2010). Fizikai szinten különböző testi és viselkedéses tünetek jelentkeznek (hasmenés, gombócérzés a torokban, sápadtság, szívdobogás, összehúzott testtartás, agresszív viselkedés, szétesett mozgás stb.). Az érzelmi szinten megjelenő szorongás egyfajta feszült, kellemetlen lelki állapotot takar, míg értelmi szinten negatív gondolatok jelenhetnek meg (például „csak vele ne kerüljek össze a versenyen”) és a kognitív funkciók is csökkenhetnek (csökkenő koncentráció és figyelem stb.)

A szorongás megnövekedett arousal-szinttel jár együtt, ami meghatározza a sportteljesítményt. Az arousal szintnek megfelelően debilizáló és facilitáló szorongásról beszélhetünk. A facilitáló szorongás ahhoz a tartományhoz köthető, amelyen belül a teljesítőképesség optimális. Az optimálisnál magasabb arousal-szint káros a teljesítményre, mivel dezorientálja a pszichikus müködést: ez a debilizáló vagy paralizáló szorongás (Horváth és Prisztóka, 2005). Ugyanakkor a túl alacsony szintü arousal sem kedvező, mert motiválatlanságot mutat, amelynek a következménye az alacsony teljesítmény. Parfitt, Jones és Hardy (1990) megállapította, hogy egyes sportolók képesek a szorongást pozitív módon interpretálni. Két sportoló megélheti ugyanolyan fokú és intenzitású szorongást, ám individuális különbségeikből fakadóan az egyik sportoló számára ez facilitáló, míg a másik számára debilizáló (Marchant és Morris, 2005). Kutatások azt bizonyítják, hogy a szorongás és a distressz általában a teljesítmény romlásához vezet, míg az eustressz vagy a magas arousal szint elősegítheti a sikert, ha a helyzet kontrollálásának érzete is jelen van a sportolóban (Csíkszentmihályi és Jackson 2001; Landers és Arent 2001; Smith és Smoll 2004).

Számos tényező húzódhat meg a sportoló szorongásának hátterében, a sportolók könnyen kerülhetnek relaxált állapotból feszült állapotba vagy fordítva, saját teljesítményük és a játék kontextusának észlelése alapján. A jelentkező szorongás intenzitása és jeleinek manifesztálódása személyenként és helyzetenként eltérö, illetve a személy készségszintje és a sport típusa is befolyásolhatja a feladat nehézségének, időtartamának és típusának megfelelően (például egyéni vagy csapatsport, közvetlen vagy közvetett konfliktusok vannak jelen, stb.) (Marchant és Morris, 2005). Megjelenhet teljesítményszorongás, általános aggodalmaskodás, szociális inkompetenciától való vagy sorozatos kudarcélmények okozta szorongás, szomatikus jellegü szorongás, de akár fóbiák, hisztérikus vagy szeparációs szorongás is (Horváth és Prisztóka, 2005).

A stressz a homeosztázis fenyegetettségét jelenti, illetve annak felborulását okozza, amely kontrollvesztéssel jár. Selye (1963) szerint a testi és lelki megterhelések a szervezet stressz- 
reakcióját idézik elő, amelyek az adaptáció szolgálatában állnak. A stresszorokat, vagyis a fenyegetést jelentő ingereket csoportosíthatjuk a szervezetre ható ingerek erőssége szerint. A túl kevés és a túl nagy ingerlés egyaránt stresszkeltő. Az alacsony ingerlési szint következtében unalom lép fel, a túlzott ingerlés pedig bénultsághoz vezet s mindkét folyamat a teljesítmény rovására megy. A stressz azonban nem mindig negatívan jelentkezik. A negatívan értékelt stressz a distressz, ám beszélhetünk pozitív stresszről, azaz eustresszről is. Ekkor valamilyen pozitív esemény áll a háttérben, amelyet pozitív gondolatok kísérnek, míg distressz esetén ez negatív színezetü, negatív gondolatokkal.

A megküzdéshez köthető szerves fogalom a pszichológiai immunrendszer. Oláh Attila szerint ,a pszichológiai immunrendszer fogalma azoknak a személyiségforrásoknak a megjelölésére szolgál, amelyek képessé teszik az egyént a stresszhatások tartós elviselésére, a fenyegetésekkel való eredményes megküzdésre" (Oláh, 2005, 85. o). A pszichológiai immunitás egy aktív védettség, amely ekkor jelenik meg, ha az integrált pszichikus müködésben probléma jelentkezik vagy az egyén pszichikus fejlödését és céljainak realizálását veszély fenyegeti (Oláh, 2005).

A pszichológiai immunrendszer felépítése három alrendszerre tagolható, amelyek egymással szoros kapcsolatban állnak. Ezek több tulajdonságot foglalnak magukba, amelyek a következők:

- megközelítö, monitorozó rendszer: pozitív gondolkodás, kontrollképesség, koherencia érzék, növekedésérzés, rugalmasság és kihívásvállalás, empátia és a monitorozás képessége, valamint célorientáció;

- mobilizáló, alkotó és végrehajtó rendszer: leleményesség, énhatékonyság, társas forrásmobilizálás képessége, társas alkotóképesség, valamint öntisztelet;

- self-reguláló rendszer: szinkronképesség, impulzivitáskontroll, érzelmi kontroll, valamint ingerlékenység kontroll.

Az egészségesség kulcsa a stresszel való hatékony megküzdés, a személyiség-komponensek müködésének hatékonysága és az egészség-betegség dimenzió kölcsönösen hatnak egymásra. A pszichológiai immunkompetencia gyengesége patológiás állapotokat eredményez, míg a pszichés immunrendszer erőssége az egészséggel és a tünetmentességgel korrelál (Oláh, 2005).

A copingstratégiákat tekintve - akárcsak a stressz esetén - beszélhetünk pozitív és negatív megküzdésről. Pozitív megküzdés során nem jelentkeznek mellékhatások, míg negatív stresszcsökkentő módszer alkalmazása során valamilyen káros hatás is fellép. Ezek alapján pozitív coping pl. a sport, a relaxáció, a humor, a nevetés, vagy a sírás, míg negatív copingra példa lehet az alkohol, a kábítószer vagy az evés is (Kopp, 1995). A negatív megküzdési stratégiák hasznosak lehetnek a megküzdési folyamat során, ugyanakkor magukban rejtenek egyfajta kockázatot is, például a dohányzás egészségügyi problémák okozója lehet. A sport egy pozitív copingstratégia, hiszen a megfelelő mértékben üzött sporttevékenység képes csökkenteni a feszültséget, helyreállíthatja a szervezet egyensúlyát és nem okoz káros mellékhatásokat.

Az alkalmazott megküzdési mechanizmusok meghatározzák magatartási döntéseinket, így az egészségmagatartásunkat is befolyásolják (Pluhár és Pikó, 2003). A megküzdési módszerünket elsődleges célunk határozza meg: problémaközpontú megküzdésről akkor beszélhetünk, ha a fókuszban a probléma megoldása áll. Ha azonban az érzelmi egyensúly áll a középpontban, érzelem-központú a megküzdési stílus (Folkman és tsai, 1986).

Nagyon fontos kérdés a sport terén is a megküzdés vizsgálata, hiszen a sportolót többféle teher is nyomasztja. Az egyik oldalon állnak az edző elvárásai, amely nagy nyomást jelent. Magasabb szinteken a sportoló menedzsere általi nyomást is meg kell említeni. Gyermek- és serdülőkorban pedig még az iskolai és szülöi elvárások is jelen vannak a gyermek életében. A sok teher az idegrendszer müködésében zavart eredményezhet, döntéseik meghozatalát is 
nehezítheti, végül teljesítményromláshoz vezethet (Frederick és Ryan, 1993, idézi Kyprianou, Sipos és Stravos, 2009). Kyprianou és tsai (2009) ciprusi férfi labdarúgók megküzdés és szorongásának vizsgálata során megállapították, hogy a felnőttekhez képest a serdülők a kedvezőtlen körülményekkel való megküzdésben, a koncentrációban és a sporttal kapcsolatos megküzdés tekintetében szignifikánsan gyengébb eredménnyel rendelkeztek, ugyanakkor a szorongás tekintetében nem mutatkozott szignifikáns különbség. Ezért is nagyon fontos, hogy a serdülők megfelelő pszichológiai felkészítést kapjanak, hogy megküzdésük fejlődhessen.

Gould és tsai (1987) végeztek kutatásokat a megküzdés terén. Birkózókkal készített interjúkat az észlelt stresszel való megküzdés tekintetében. Az eredmények alapján négy dimenzióba voltak süríthetők a megküzdési módok: voltak kontroll stratégiák, mint a pozitív gondolkodás vagy a megküzdő gondolkodás; feladat-fókuszú megküzdés, ami magába foglalja a feladatra irányuló szűk fókuszú figyelem fenntartását. Ezen kívül érzelmi kontroll stratégiákat is elkülönítettek, amelyek elsősorban az érzelmek és izgalmi állapot feletti kontroll fenntartására irányuló erőfeszítésekre vonatkoznak; valamint viselkedéses stratégiákat, amelyek az olyan viselkedésekre vonatkoznak, amelyek megváltoztatták vagy kontrollálták a környezetet (Marchant és Morris, 2005).

Omar-Fauzee és tsai (2009) a képzeleti módszerek és coping stratégiák hatékonyságát vizsgálta arra a feltételezésre alapozva, hogy ez a két mentális képesség hozzájárul a sportolók sikeres teljesítményéhez. A vizsgálati mintában elsősorban maláj személyek szerepeltek (kínai, indiai stb. személyek mellett), az űzött sportágak széles körét lefedve (futball, futsal, röplabda, kosárlabda, rögbi, úszás, jéghoki, íjászat, stb.), illetve a sportolók különböző szinteken sportoltak (területi/egyetemi, országos vagy nemzetközi szinten). Az eredmények azt mutatták, hogy a különböző szinten sportoló személyek között szignifikáns különbség áll fenn mind a képzeleti stratégiák alkalmazása, mind a sportolói megküzdés tekintetében. A legmagasabb szinten (nemzetközi) sportolók mind a képzeleti módszerek, mind a megküzdés tekintetében jobban teljesítettek, mint a másik két csoport.

\section{Módszer}

A tanulmányban a sportolás önértékelésre, szorongásra, pszichológiai immunkompetenciára és teljesítményigényre gyakorolt hatásait vizsgáljuk prepubertás korú fiúk körében. A vizsgálódás során a sportoló és nem sportoló gyerekek közötti különbségek felderítése, illetve a felsorolt változók egymás közötti kapcsolatának feltérképezése volt a célunk. A kutatás során a következő hipotéziseket állítottuk fel:

H1: A sportoló gyerekek önértékelése és megküzdése jobb, teljesitményigényük magasabb, ugyanakkor szorongásuk szintje alacsonyabb nem sportoló társaikkal összehasonlítva.

H2: A vizsgált változók egymással összefüggenek: magasabb önértékelés jobb megküzdéssel és a teljesítményigény és a szorongás alacsonyabb szintjével jár együtt; alacsonyabb szorongás jobb megküzdéssel társul és alacsonyabb teljesítményigénnyel jár együtt; emellett a jobb megküzdéssel alacsonyabb szintü teljesítményigény korrelál.

\section{Minta}

A vizsgálati minta 11 és 13 év közötti fiúkból állt. A mintában csak fiúk szerepelnek, tekintettel arra, hogy ebben az életkorban a lányok önértékelése instabilabb, mint a fiúké. A minta egyik csoportja a Debreceni Sportcentrum és Sportiskola kézilabdázói, tehát aktív sportolók, összesen 47 fö, átlagéletkoruk 12,1 év. A vizsgálati minta másik részét olyan gyerekek tették ki, akik nem végeznek rendszeres sporttevékenységet, ők a Kazinczy Ferenc Alapfokú Művészeti Iskola diákjai, összesen 46 fó, átlagéletkoruk 12,4 év. A minta nem volt reprezentatív. 


\section{Eszközök}

A tesztbattéria elemei a Coopersmith-féle önértékelési kérdőív, a Gyermek vonás és állapotszorongás kérdőív állapotszorongást mérő része, a Pszichológiai Immunkompetencia Junior kérdőív, illetve a Teljesítményigény kérdőív.

A Coopersmith-féle önértékelési kérdöív kitöltése (Coopersmith, 1984) 50 állítást tartalmaz a gyermek önértékelésének feltérképezésére. Öt alskálát tartalmaz: az S skála közvetlenül a szelfre vonatkozó adatokat gyüjti, a gyermek magabiztosságát és önmagával való elégedettségét foglalja magába. Az I skála az iskolára és az iskolai teljesítményre vonatkozik, az O skála az otthoni hatások önértékelésre gyakorolt szerepét figyeli. A T skála az egykorú társakkal kapcsolatos önértékelést méri, míg az L skála a szociális konformizmus skálája. Az első négy skála tartalmazza tehát az önértékelés különbözö összetevőit, az ötödik pedig egy ellenőrző skálaként szolgál.

A Spielberger féle Vonás- és állapotszorongás Kérdőív (1973) gyermek változata, ennek is a vonásszorongást mérő kérdéssorozat. Ennek megfelelően a gyerekeknek a felsorolt állításokról kell eldönteniük, hogy általában véve szinte soha, néha, vagy pedig gyakran jellemzőek rá.

A Teljesítményigény kérdőív (Tóth, 2005) 22 állítást tartalmaz, amely alapján megállapítható, hogy a gyermek sikerkereső-e, vagy inkább kudarckerülő típusú. A sportoló gyerekek számára a kérdések arra vonatkoztak, hogy a sportra vonatkozóan jellemzőek-e rá az állítások, míg azok a gyerekek, akik nem sportolnak, azt a feladatot kapták, hogy kedvenc tantárgyukra vonatkozóan jellemzőek-e rá a kijelentések.

Végül a PIK junior kérdőív (Oláh, 2005) a gyerekek pszichológiai immunrendszerének mérésére. A kérdőív 16 személyiségdimenziót mér, három alrendszer részeként, ezekhez kapcsolódik a 48 állítás, amelyeket négyfokú Likert-skálán kell megítélni, hogy azok mennyire jellemzőek a személyre.

\section{Eljárás}

A tesztkitöltés személyesen történt meg. Ez két részletben történt meg: az első részletben a Coopersmith-féle önértékelési teszt és a Vonásszorongás teszt felvételére került sor, majd a második részletben történt a teljesítményigény és a pszichés megküzdés felmérése. A gyerekek számára nem volt meghatározva konkrét időintervallum, átlagosan 20 perc alatt töltötték ki a tesztbattéria első, illetve a második felét is.

$\mathrm{Az}$ adatok statisztikai értelmezése az $\mathrm{R}$ statisztikai program alkalmazásával történt. $\mathrm{A}$ vizsgált változók az énkép, szorongás, teljesítményigény és pszichológiai immunkompetencia voltak.

\section{Eredmények}

Az adatok feldolgozását normalitás vizsgálatok lefuttatásával kezdtük, amelyhez Kolmogorov-Smirnov próbát alkalmaztunk. A próba eredményei azt mutatták, hogy a minta eloszlása nem normális, ezért a továbbiakban nem paraméteres eljárásokat alkalmaztunk.

A „sportoló gyerekek önértékelése és megküzdése jobb, teljesítményigényük magasabb, ugyanakkor szorongásuk szintje alacsonyabb nem sportoló társaikkal összehasonlítva" hipotézissel kapcsolatos eredmények: a sportoló és nem sportoló csoportok énképének, szorongásának, pszichológiai immunkompetenciájának és teljesítményigényének eredményeit az 1. táblázat tartalmazza.

A hipotézis teszteléséhez az adatok nem normális eloszlására való tekintettel Mann-Whitney próbát alkalmaztunk. 
1. táblázat: eredmények a sportolók és nem sportolók körében (forrás: a Szerzők)

\begin{tabular}{|l|l|r|r|r|r|}
\hline \multirow{4}{*}{ csoportol } & Statisztika & Énkép & Szorongás & PIK & Teljesítmény \\
\hline & Átlag & 82,81 & 29,59 & 147,51 & 8,09 \\
\cline { 2 - 6 } & Medián & 86,00 & 28,00 & 148,00 & 8,00 \\
\cline { 2 - 6 } & Szórás & 13,82 & 6,22 & 18,98 & 1,99 \\
\cline { 2 - 6 } & Minimum & 44,00 & 20,00 & 99,00 & 4,00 \\
\cline { 2 - 6 } & Maximum & 100,00 & 57,00 & 178,00 & 13,00 \\
\hline nem sportol & Átlag & 71,61 & 32,02 & 136,63 & 9,35 \\
\cline { 2 - 6 } & Medián & 72,00 & 31,00 & 136,00 & 9,00 \\
\cline { 2 - 6 } & Szórás & 12,92 & 5,80 & 17,25 & 2,13 \\
\cline { 2 - 6 } & Minimum & 44,00 & 22,00 & 73,00 & 5,00 \\
\cline { 2 - 6 } & Maximum & 92,00 & 53,00 & 167,00 & 13,00 \\
\hline
\end{tabular}

A sportolók átlagosan 82,81 pontot $(S D=13,82)$ értek el az önértékelési teszten. A nem sportolók az önértékelési tesztre kapott pontjainak átlaga 71,61 pont $(S D=12,92)$ volt. A Mann-Whitney próba eredménye alapján a két csoport közötti eltérés mértéke szignifikáns $(U=525.5, W=1606.5, Z=-4.27, p<0,05)$, vagyis a sportoló kiskamaszok önértékelése jobb, mint a nem sportoló kiskamaszoké.

A Vonásszorongás skálán a sportolók átlagpontszáma 29,59 pont $(S D=6,22)$, míg a nem sportolóké 32,02 pont $(S D=5,80)$ volt. A Mann-Whitney próba eredménye alapján a két csoport közötti különbség szignifikáns $(U=769.5, W=1897.5, Z=-2.40, p<0,05)$. A vizsgálat a vártnak megfelelő eredményt hozta, vagyis a sportoló gyerekek valóban kevésbé szorongóak, mint nem sportoló társaik.

A sportoló kiskamaszok a PIK kérdőíven elért átlagos pontszáma 147,51 pont lett $(S D=1,98)$, ezzel szemben a nem sportoló csoport átlagosan elért pontszáma 136,63 volt $(S D=17,25)$. A Mann-Whitney próba ebben az esetben is szignifikáns különbséget mutatott ki $(U=730.5, W=1858.5, Z=-2.72, p<0,05)$. Így levonható a következtetés, hogy a sportoló prepubertások pszichológiai immunkompetenciája jobbnak bizonyult, mint a nem sportoló prepubertásoké.

Végül a sportoló kiskamaszok teljesítményigénye átlagosan 8,09 pont $(S D=1,99)$, míg a nem sportolók teljesítményigénye átlagosan 9,35 pont volt $(S D=2,13)$. A Mann-Whitney próba alapján a két csoport közti különbség ebben az esetben is szignifikáns volt $(U=707.5$, $W=1788.5, Z=-2,87, p<0,05)$, azonban ebben az esetben az eredményeim a várakozásunkkal ellentétesen alakultak, ugyanis a vizsgálat során a nem sportoló gyerekek teljesítményigénye magasabbnak mutatkozott, mint a sportolóké. Mivel a két csoport közötti eltérés szignifikánsnak mutatkozott, az a következtetés vonható le, hogy ebben a mintában a nem sportoló gyerekek teljesítményigénye szignifikánsan magasabb volt, mint a sportoló gyerekeké.

A vizsgált változók együttjárásával kapcsolatos hipotézis vizsgálatának eredményei: a hipotézis teszteléséhez az adatok nem normális eloszlására való tekintettel Spearman-féle rangkorrelációs eljárást alkalmaztunk.

Az énkép és a szorongás között pozitív kapcsolatot feltételeztünk. Az eredmények a várakozásnak megfelelően alakultak, a két változó között közepes erősségű negatív korreláció mutatkozott $\left(r_{s}=-0,62 ; p<0,01\right)$. Ez alapján jobb önértékelés a szorongás alacsonyabb szintjével jár együtt. 
Az énkép és a teljesítményigény között -a szorongáshoz hasonlóan- fordított kapcsolatot feltételeztünk. A Spearman-féle rangkorreláció mérsékelt negatív kapcsolatot mutatott a két változó között $\left(r_{s}=-0,34 ; p<0,01\right)$. Ez alapján a magasabb önértékelés inkább alacsonyabb teljesítményigénnyel korrelál.

Elözetesen azt feltételeztük, hogy az énkép és a pszichológiai immunkompetencia között pozitív korreláció áll fenn, amelyet a statisztikai eredmények megerősítettek, hiszen ez alapján erős pozitív kapcsolat feltételezhető a változók között $\left(r_{s}=0,75 ; p<0,01\right)$. Így megállapítható, hogy minél jobb a gyermek önértékelése, annál magasabb a pszichológiai immunkompetenciája, tehát jobb a megküzdési képessége is.

A szorongás és a teljesítményigény között szintén pozitív kapcsolatot vártunk. A korrelációs teszt lefuttatása során kapott eredmény közepes mértékü pozitív kapcsolatot mutatott ki a vizsgált változók között $\left(r_{s}=0,49 ; p<0,01\right)$. Ez azt jelenti, hogy minél magasabb a gyermek szorongásának mértéke, annál magasabb a teljesítményigénye is, ugyanakkor alacsonyabb szintü szorongás alacsonyabb szintü teljesítményt vonz magával.

A szorongás és pszichológiai immunkompetencia között negatív kapcsolatot feltételeztünk. A korrelációs eljárás ezt megerősítette, hiszen közepes mértékü negatív kapcsolatot mutatott a változók között $\left(r_{s}=-0,54 ; p<0,01\right)$. Így megállapíthattuk, hogy minél szorongóbb a gyermek, annál rosszabb a megküzdési készsége, illetve minél kevésbé szorong a gyermek, annál jobb a pszichológiai immunkompetenciája. A PIK és a szorongás közti kapcsolat mélyebb feltárása érdekében a PIK valamennyi alskáláját korreláltattuk a szorongással, amelynek eredményeit a 2. táblázat szemlélteti.

Az összesített eredményeknek megfelelően az egyes alskálák is negatív irányú kapcsolatban állnak a szorongással. A különböző alskálák szorongással történt korreláltatása során szinte minden vizsgálatra kapott eredmény szignifikánsnak bizonyult. Az egyes alskálák közül a kontrollképességgel mutatta a legerösebb korrelációt a szorongás mértéke, ugyanakkor a koherencia érzék, a forrás-teremtőképesség és a szociális forrás-mobilizáló képesség nem mutatott szignifikáns mértékü korrelációt a szorongással.

2. táblázat: a PIK alskálái és a szorongás korrelációi (forrás: a Szerzők)

\begin{tabular}{|l|c|}
\hline \multicolumn{1}{|c|}{ Szorongással mért korrelációk } & Rangkorrelációs érték $\left(\boldsymbol{r}_{\boldsymbol{s}}\right)^{*}$ \\
\hline Optimizmus & $-0,41$ \\
\hline Koherencia érzék & $n . \mathrm{s}$. \\
\hline Kontrollképesség & $-0,51$ \\
\hline Növekedés-érzés & $-0,46$ \\
\hline Forrás-monitorozó képesség & $-0,24$ \\
\hline Forrás-mobilizáló képesség & $-0,32$ \\
\hline Forrás-teremtó képesség & $n . s$. \\
\hline Kitartás & $-0,26$ \\
\hline Szociális forrás-monitorozó képesség & $-0,36$ \\
\hline Szociális forrás-mobilizáló képesség & $n . s$. \\
\hline Szociális forrás-teremtö képesség & $-0,12$ \\
\hline Öntisztelet & $-0,44$ \\
\hline Szinkronképesség & $-0,44$ \\
\hline Impulzivitás kontroll & $-0,45$ \\
\hline Ingerlékenység kontroll & $-0,35$ \\
\hline Emocionális kontroll & $-0,44$ \\
\hline * $\boldsymbol{p} \leq \mathbf{0 , 0 5}$ & \\
\hline
\end{tabular}


Végül a pszichológiai immunkompetencia és a teljesítményigény közötti kapcsolatot is megvizsgáltunk, amelyek között elözetesen fordított kapcsolatot feltételeztünk. Hipotézisünk beigazolódott, hiszen a korrelációs eljárás mérsékelt negatív irányú kapcsolatot mutatott a vizsgált változók között $\left(r_{s}=-0,374 ; p<0,01\right)$. Így megállapítható, hogy a jobb megküzdés alacsonyabb teljesítményigénnyel jár együtt.

\section{Megvitatás}

Kutatásunk a sportolás énképre, szorongásra, teljesítményigényre és pszichológiai immunkompetenciára gyakorolt hatásira irányult kiskamaszok körében.

A serdülőkor az identitás kialakulásának időszaka, életünk egyik legnehezebb része, a gyermek ekkor alakítja ki identitását, megalapozza későbbi önértékelését és megküzdési mechanizmusait is. Számos tényező befolyásolja ezt a folyamatot: család, barátok, környezet, társadalmi helyzet, stb. Ilyen tényező a sportolás is. Korábbi kutatások a sportolás számos jótékony hatásairól számolnak be: fiziológiai és pszichológiai szempontból is egészségesebb életet kínál.

Kutatásunk első részében a sportolás énképre, szorongásra, teljesítményigényre és pszichológiai immunkompetenciára gyakorolt hatását vizsgáltuk prepubertások körében. Minden tekintetben szignifikáns különbség mutatkozott a sportoló és nem sportoló gyerekek közt: a sportoló gyerekek énképe és pszichológiai immunkompetenciája jobbnak és hatékonyabbnak bizonyult a nem sportolókénál, illetve szorongásuk szintje is alacsonyabb, mint azoké a gyerekeké, akik nem végeznek rendszeres tevékenységet. Ugyanakkor a teljesítményigény és a sportolás közötti kapcsolat nem a várakozásunknak megfelelően alakult, hiszen elözetesen azt feltételeztük, hogy a sportolók teljesítményigénye magasabb lesz a nem sportolókkal szemben, ám az eredmények alapján ennek ellentéte bizonyosodott be.

Ezek az eredmények megerősítik a korábbi kutatások eredményeit, mely szerint a sportolók énképe, szorongási és megküzdési mechanizmusai jobbak már prepubertás korban is. Ugyanakkor korábbi feltételezésünk, mely szerint a sportoló gyerekek teljesítményigénye magasabb nem sportoló társaikkal összehasonlítva nem igazolódott, pontosabban éppen az ellentéte mutatkozott, hiszen a nem sportoló gyerekek teljesítményigénye szignifikánsan magasabbnak bizonyult.

Ennek hátterében a reális önértékelésben állhat. Ha a sikerorientált és kudarckerülő embereket nézzük, láthatjuk, hogy a reális önértékelés akkora teljesítményigénnyel jár együtt, amennyit a személy képes vállalni. Az alacsony önértékelés azonban együtt járhat alacsony teljesítményigénnyel, ugyanakkor magas teljesítményigénnyel is, amely nem reális. Azt feltételeztük, hogy a sportolás egyik következménye lehet a magas teljesítményigény, mivel a sportolók számára fontos, hogy téthelyzetben kiválóan teljesítsenek. A kutatás alapján azonban úgy tünik, hogy a magas teljesítményigény nem feltétlen velejárója a téthelyzeteknek, így a sportolók körében inkább alacsonyabb a teljesítményigény, kapcsolódva a reális önértékeléshez.

A kutatás részét képezte továbbá az énkép, szorongás, pszichológiai immunkompetencia és teljesítményigény közötti kapcsolatok vizsgálata. Az eredmények reflektálnak a szakirodalom korábbi megállapításaira: a magasabb önértékelés együtt jár a hatékonyabb megküzdési mechanizmusokkal, ugyanakkor alacsonyabb szorongásszintet és teljesítményigényt is feltételez. A szorongás magasabb szintje együtt jár a teljesítményigény, a megfelelni vágyás magasabb szintjével, emellett a magasabb szintü szorongás negatívabb önértékeléssel és gyengébb megküzdési kompetenciákkal korrelál. Emellett a magasabb teljesítményigény is negatívabb önértékeléssel, magasabb szorongással, ám gyengébb megküzdési kompeten- 
ciákkal jár. Ennek hátterében az állhat, hogy az önértékelés, szorongás és a megküzdés egymást kölcsönösen befolyásoló tényezők, az egyikben bekövetkező változás a többi tényezőben is változásokat eredményez.

\section{Korlátozások}

A minta a speciális csoport miatt alacsony létszámú volt, hiszen három, ennek az életkornak megfelelő fiú kézilabda csapatból állt. Ahhoz, hogy pontosabb eredmények kimutatására kerüljön sor, érdemes lenne a teszteket egy nagyobb mintán is felvenni, hiszen minél nagyobb egy vizsgálati minta, annál nagyobb biztonsággal jelenthetők ki statisztikailag helytálló eredmények. Továbbá a későbbiekben érdemes lenne lányok körében is elvégezni a kutatást, amely a nemek közti különbségekre is rávilágíthatna.

Fontos továbbá megjegyezni, hogy a vizsgálat csak a változók közti kapcsolatok mértékének felderítésére irányult, így az ok-okozati tényezők ebben az esetben háttérbe szorultak. Ennek feltárása későbbi kutatások alapját képezheti.

Jelen kutatásban csak kézilabdázó gyerekek vettek részt, ám érdemes sportágak szerint is megvizsgálni ezeket a személyiségtényezőket, amelyhez ezek az eredmények jó alapot biztosíthatnak. Továbbá érdemes lenne összehasonlítani a csapatsportoló és egyéni sportolók között fennálló lehetséges különbségeket. A személyiség fejlődésében a sport hatására kialakuló változások longitudinális vizsgálat során még jobban detektálhatók.

\section{Konklúziók}

Kutatásunk célja a sportolás énképre, szorongásra, teljesítményigényre és pszichológiai immunkompetenciára gyakorolt hatásainak vizsgálata volt. $\mathrm{Az}$ eredmények alapján megállapítható, hogy a sportolás pozitívan hat a gyerekek énképére és megküzdésére, csökkenti a szorongás mértékét, ugyanakkor alacsonyabb teljesítményigénnyel jár együtt. Emellett megállapíthattuk, hogy a magasabb önértékelés hatékonyabb pszichológiai immunkompetenciával, alacsonyabb szorongással és alacsonyabb önértékeléssel jár együtt, emellett magasabb szorongás alacsonyabb megküzdési kompetenciával, ám magasabb teljesítményigénnyel korrelál, míg a magasabb pszichológiai immunkompetencia (az énképhez hasonlóan) alacsonyabb teljesítményigénnyel kapcsolódik össze.

A kapott eredmények rámutatnak a sportolás következtében az önértékelésben, szorongásban, teljesítményigényben és megküzdésben fennálló különbségekre. Továbbá a vizsgált változók egymásra gyakorolt hatását tekintve a kapott eredményeket felhasználhatjuk a mindennapok során is. Azoknál a gyerekeknél, ahol az önértékelés alacsonyabb szintje látható, nagy valószínüséggel megjelenik a magasabb fokú szorongás vagy a rosszabb megküzdés. Sportolók esetében a szülők mellett az edző feladata is, hogy ilyen esetben az edzések alkalmával javítsa a gyermek önértékelését, vagy csökkentse a szorongását, hiszen ezzel a gyermek szenvedéseit is csökkenti, valamint a gyermek pályán nyújtott teljesítményét is javíthatja. A feltárt kapcsolatok segíthetnek abban, hogy a szülők vagy az edző könnyebben átláthassa a problémát és ezzel könnyebben orvosolják is azt.

A vizsgálat megerősíti a korábbi kutatási eredményeket, mely szerint a sportolás jótékonyan hat a gyerekek önmagáról kialakított elképzeléseire, és mivel ez meghatározza a gyermek későbbi gondolkodását és fejlődését is, fontos hangsúlyozni, hogy a sport hatékony változó az önértékelés és a megküzdés fejlesztésében vagy a szorongás csökkentésében.

\section{Irodalom}

Ajzen, I. (2011). The theory of planned behaviour: reactions and reflections. Psychology \& Health, 26, 1113-1127. 
Atkinson R. L. és Hilgard, E. R. (2005). Pszichológia. Osiris Kiadó, Budapest.

Coopersmith, S. (1984). Coopersmith Self-Esteem Inventory. Palo Alto, CA: Consulting Psychologists Press.

Csíkszentmihályi, M. és Jackson, S. A. (2001). Sport és flow. Az optimális élmény. Vince Kiadó Kft., Budapest.

Eccles, J. S. és Harold, R. D. (1991). Gender differences in sport participation: Applying the Eccles' expectancy model. Journal of Applied Sports Psychology, 3, 7-35.

Fletcher, A. C., Nickerson, P. és Wright, K. L. (2003). Structured leisure activities in middle childhood: Links to well-being. Journal of Community Psychology, 31, (6), 641-659.

Folkman, S., Lazarus, R. S., Gruen, R. J. és DeLongis, A. (1986). Appraisal, coping, health status. and psychological symptoms. Journal of Personality and Social Psychology, 50, 571-579.

Frederick, C. M. és Ryan, R. M. (1993). Differences in motivation for sport and exercise and their relations with participation and mental health. Journal of Sport Behavior, 16, 124146.

Gould, D, Petlichkoff, L., Simons, J. és Veera, M. (1987). Relationship between competitive state anxiety inventory-2 subscale scores and pistol shooting performance. Journal of Sport Psychology, 9, 33-42.

Gyömbér N. és Kovács K. (2012). Pici lábak a pályán, avagy a fiatalkori sport pszichológiája. In: Gyömbér N. és Kovács K. (2012). Fejben döl el. Sportpszichológia mindenkinek. NORAN LIBRO, Budapest, 2012. 191-220.

Hansen, D. (2006). Conceptual categories of organized youth activities: Refining categories. Presented at the Biennial meeting of the Society for Research in Adolescence. San Francisco, CA.

Horn, T. S. és Hasbrook, C. A. (1987). Psychological characteristics and the criteria children use for self-evaluation. Journal of Sport Psychology, 9, 208-221.

Jacobs, J. E., Lanza, S., Osgood, D. W., Eccles, J. S. és Wigfield, A. (2002). Changes in children's self-competence and values: Gender and domain differences across grades one through twelve. Child Development, 73, (2), 509-527.

Kopp M. és Skrabski Á. (1995). Magyar lelkiállapot. Végeken Kiadó, Budapest.

Kyprianou, P., Sipos K. és Stavros S. (2009). Sportolói megküzdési stratégiák és versenyzéssel kapcsolatos szorongás vizsgálata ciprusi labdarúgóknál. Magyar Sporttudományi szemle, 10, (37), 7-10.

Landers, D. M. és Arent, S. M. (2001). Arousal-performance relationship. In: Williams, J. M. (szerk.): Applied Sport Psychology, Personal Growth to Peak Performance. Mayfield Publishing company, Montain View, California.

Lénárt Á. (2002). Néhány gondolat a gyerekek sporttal kapcsolatos motivációjáról. In: Lénárt Á. (szerk): Téthelyzetben. Sportpszichológiáról edzöknek és versenyzőknek. Országos Sportegészségügyi Intézet, Budapest. 95-96.

Liebert, R. M. és Morris, L. W. (1967). Cognitive and emotional components of test anxiety: a distinction and some initial data. Psychological reports 30, 975-978.

Mahoney, J. L., Larson, R. W., Eccles, J. E. és Lord, H. (2005). Organized activities as developmental contexts for children and adolescents. In J. L. Mahoney, R. W. Larson és J. S. Eccles (szerk): Organized activities as contexts of development: Extracurricular activities, after-school, and community programs. Mahwah, NJ: Lawrence Erlbaum Associates, 3-22.

Marchant, D. B. és Morris, T. (2005). Stress and anxiety in sport. In: Morris, T. és Summers, J. (szerk): Sport psychology: theory, applycations and issues. John Wiley \& Sons Australia, Ltd, 2005. 75-101. 
Marsh, H. W., Gerlach, E., Trautwein, U., Ludtke, O. és Brettschneider, W. (2007). Longitudinal study of preadolescent sport self-concept and performance: Reciprocal and causal ordering. Child Development, 78, 1640-1656.

Oláh A. (2005): Érzelmek, megküzdés és optimális élmény. Trefort. 52-110.

Omar-Fauzee, S., Wan Rezawana, B. W. D., Abdullah, R. és Rashid, S. A. (2009). The Effectiveness of Imagery and Coping Strategies in Sport Performance. European Journal of Social Sciences, 9, (1).

Orosz R. (2010): A sporttehetség felismerésének és fejlesztésének pszichológiai alapjai. Magyar Tehetségsegítő Szervezetek Szövetsége, 2010. 30-55.

Parfitt, C. G., Jones, J. G. és Hardy, L. (1990). Multidimensional anxiety and performance. In: Jones, J. G. és Hardy, L (szerk): Stress and performance in sport. John Wiley \& Sons, Chichester, UK, 43-80.

Pate, R. R., Heath, G. W., Dowda, M. és Trost, S. G. (1996). Associatins between physical activity and other health behaviors in a representative sample of US adolescents. American Journal of Public Health, 86, 1577-1781.

Pikó B. és Keresztes N. (2007). A sport egészségpszichológiája. A sportolási gyakoriság hatása serdülő fiatalok életcéljaira, értékorientációira és pszichoszociális egészségére. In: Pikó B. és Keresztes N. (2007): Sport, lélek, egészség. 119-133.

Pikó B. és Keresztes N.(2007). Serdülők egészségmagatartása két szociális megküzdési (coping) mechanizmus tükrében. Magyar Pszichológiai Szemle, 62, (2), 203-214.

Pluhár, Zs., Keresztes, N. és Pikó, B. (2004). A rendszeres fizikai aktivitás és pszichoszomatikus tünetek kapcsolata általános iskolások körében. Sportorvosi szemle, 4, 285-300.

Pluhár Zs. és Pikó B. (2003). A sport előfordulása és esetleges preventív hatása fiatalok körében. Magyar Sporttudományi Szemle, 1, 26-29.

Roberts, G. C. és Treasure, D.C. (1992). Children in sport. Sport Science Review, 1 (2), 46-64.

Selye J. (1963): Életünk a stressz. Akadémiai kiadó, Budapest.

Simpkins, S. D., Fredricks, J., Davis-Kean, P. és Eccles, J. S. (2006). Healthy minds, healthy habits: The influence of activity involvement in middle childhood. In: Huston, A. és Ripke, M. (szerk): Developmental contexts in middle childhood: Bridges to adolescence and adulthood. NewYork: Cambridge University Press. 283-302.

Slutzky, C. B. és Simpkins, S. D. (2008). The link between children's sport participation and self-esteem: exploring the mediating role of sport self-concept. Psychology of Sport and Exercise, 2009, 10, 381-389.

Smith, R. E. és Smoll, (2004). Anxiety and coping in sport: theoretical models and approaches to anxiety reduction. In Morris, T. \& Summers, J. (szerk): Sport Psychology: Theory, Applications and Issues. John Wiley and Sons, Brisbane, Australia, 294-321.

Smoll, F. L. (1998). Improving the quality of coach-parent relationship in youth sport. In: Williams, J. M. (szerk): Applied sport psychology. Personal growth to peak performance. New York, McGraw-Hill.

Spielberger, C.D., Edwards C.D., Montuori J. és Lushene R. (1973). State-Trait Anxiety Inventory for Children. Palo Alto, CA: Consulting Psychologist Press.

Spielberger, C. D. (1975). Anxiety: State-trait process. In: Spielberger, C. D és Sarason, I. G. (szerk): Stress and anxiety. (1). Hemisphere, New York. 115-143.

Steptoe, A., Wardle, J., Fuller, R., Holte, A., Justo, J., Sanderman, R. és Wichstorm, L. (1997). Leisure-time physical exercise: prevalence, attitudinal correlate, and behaviorial correlates among young Europeans from 21th centuries. Preventive Medicine, 26, 845-854.

Stuller Gy. (1995). A sport személyiségalakító hatása. In: Stuller Gy. (szerk): A pszichológia és a sportpszichológia alapjai. Recrus Kft., Budapest, 213-219. 
Tóth L. (2005). Pszichológiai vizsgálati módszerek a tanulók megismeréséhez. Pedellus Tankönyvkiadó, Debrecen.

Vajda Zs. (2006). A gyermek pszichológiai fejlödése. Helikon Kiadó. 217-263.

Vilhjalmsson, R. és Thorlindsson, T. (1992): The Integrative and Physiological Effects of Sport Participation: A Study of Adolescents. Sociological Quarterly, 33, 637-647. 